University of Nebraska - Lincoln

DigitalCommons@University of Nebraska - Lincoln

\title{
Numerical Modeling of Bank Instability by Seepage Erosion Undercutting of Layered Streambanks
}

\author{
M. L. Chu-Agor \\ Oklahoma State University
}

G. V. Wilson

USDA-ARS

G. A. Fox

Oklahoma State University, gafox2@ncsu.edu

Follow this and additional works at: https://digitalcommons.unl.edu/usdaarsfacpub

Part of the Agricultural Science Commons

Chu-Agor, M. L.; Wilson, G. V.; and Fox, G. A., "Numerical Modeling of Bank Instability by Seepage Erosion Undercutting of Layered Streambanks" (2008). Publications from USDA-ARS / UNL Faculty. 476. https://digitalcommons.unl.edu/usdaarsfacpub/476

This Article is brought to you for free and open access by the U.S. Department of Agriculture: Agricultural Research Service, Lincoln, Nebraska at DigitalCommons@University of Nebraska - Lincoln. It has been accepted for inclusion in Publications from USDA-ARS / UNL Faculty by an authorized administrator of DigitalCommons@University of Nebraska - Lincoln. 


\title{
Numerical Modeling of Bank Instability by Seepage Erosion Undercutting of Layered Streambanks
}

\author{
M. L. Chu-Agor'; G. V. Wilson²; and G. A. Fox, P.E., M.ASCE ${ }^{3}$
}

\begin{abstract}
Undercutting, primarily considered due to fluvial mechanisms, has been reported to have a major impact on slope failure. Predicting bank collapse specifically due to seepage erosion undercutting by particle mobilization on layered streambanks has not been fully studied or modeled, even though its role in streambank erosion may be important. The limitation originates from the limited field measurements or laboratory experiments as well as the unavailability of discrete element models that can effectively simulate seepage particle mobilization, undercutting, and the corresponding mass wasting. The objective of this research was to demonstrate a procedure for incorporating seepage undercutting into bank stability models and to investigate the role of seepage undercutting on bank instability. The question to be addressed is whether seepage particle mobilization can lead to distances of undercutting that are a significant cause of bank instability. A numerical finite-element model, SEEP/W, was used to model soil-water pressure variations during seepage observed in laboratory experiments with two-dimensional soil lysimeters. Flow parameters were calibrated using measured soil-water pressure and cumulative discharge. A general limit equilibrium bank stability model (SLOPE/W) was used to simulate bank stability with and without seepage erosion undercutting by comparing the computed factor of safety, $F s$, at different stages of the seepage erosion process with regard to input parameter uncertainty using Monte Carlo analysis. The percentage decrease in the mean $F s$ ranged between 42 and $91 \%$ as the depth of undercutting increased, dependent upon the initial stability of the bank. A stable bank (i.e., $F s>1$ ) can quickly become unstable (i.e., $F s<1$ ) when seepage undercutting is considered. For stable banks, the probability of failure reached $100 \%$ when the depth of the undercutting reached approximately 30 to $50 \mathrm{~mm}$ under these experimental conditions. The results derived are specific to the streambank simulated but are expected to be comparable for similar layered streambank lithologies reported to occur in numerous geographical locations. This research also highlights the need to incorporate the dynamic process of seepage erosion undercutting into integrated subsurface flow and streambank stability models.
\end{abstract}

DOI: 10.1061/(ASCE)1084-0699(2008)13:12(1133)

CE Database subject headings: River bank erosion; River bank stabilization; Seepage; Numerical models.

\section{Introduction}

Streambanks are one of the most vulnerable geologic structures on earth. Riverbank erosion and associated sedimentation and land loss hazards are a resource management problem of global significance (Darby et al. 2000). Issues such as streambank stability and sediment load to streams have been major concerns for decades and billions of dollars have been spent on streambank protection and restoration. Aside from being one of the major sources of fine sediment loads to streams [i.e., $75.9 \mathrm{~m}^{3}$ annual yield in the Bush River, United Kingdom which drains an area of $340 \mathrm{~km}^{2}$ and runs a distance of $60 \mathrm{~km}$ as reported by Evans et al.

\footnotetext{
${ }^{1}$ Graduate Research Assistant, Dept. of Biosystems and Agricultural Engineering, Oklahoma State Univ., 111 Agricultural Hall, Stillwater, OK 74078. E-mail: magor@okstate.edu

${ }^{2}$ Physical Hydrologist, USDA-ARS National Sedimentation Laboratory, 598 McElroy Dr., Oxford, MS 38655, E-mail: gvwilson@ars. usda.gov

${ }^{3}$ Assistant Professor, Dept. of Biosystems and Agricultural Engineering, Oklahoma State Univ., 120 Agricultural Hall, Stillwater, OK 74078 (corresponding author). E-mail: garey.fox@okstate.edu

Note. Discussion open until May 1, 2009. Separate discussions must be submitted for individual papers. The manuscript for this paper was submitted for review and possible publication on January 4, 2007; approved on February 19, 2008. This paper is part of the Journal of Hydrologic Engineering, Vol. 13, No. 12, December 1, 2008. CASCE, ISSN 1084-0699/2008/12-1133-1145/\$25.00.
}

(2006)], bank erosion and deposition processes lie at the center of understanding fluvial geomorphological processes (Lawler 2005). Bank erosion is one of the fundamental processes involved in channel migration and formation of flood plains (Hooke 1979). This is because the most important mechanisms in fluvial geomorphology are the hydraulic forces exerted by the flow (Hardy 2006).

The erosion of sediment from streambanks can be overwhelmingly dominated by mass wasting (Simon and Darby 1997). Subsurface erosion is often regarded as a process of limited importance confined to certain soils and streambank stratigraphies (Bryan and Jones 1997). The effect of seepage or subsurface flow is usually considered to be limited to the production of surface runoff and the reduction of the soil shear strength, thereby underestimating the potential effects of seepage on erosion (Owoputi and Stolte 2001). Due to the lack of knowledge and the general opinion that seepage effects are small, especially compared to other processes and forces involved, seepage effects are generally neglected in stream channel designs (Burgi and Karaki 1971). The significance of seepage erosion has not been widely recognized or understood despite the documentation of its occurrence in numerous geographical locations (Hagerty 1991; Wilson et al. 2007; Fox et al. 2007).

It is widely recognized that seepage reduces the cohesive strength and thus the bank stability by increasing soil-water pressure (Abam 1993; Darby and Thorne 1996; Crosta and di Prisco 1999; Rinaldi and Casagli 1999; Simon et al. 1999). Burgi and 
Karaki (1971) developed an empirical relationship between the seepage forces acting on the side slope of a channel and the stability of the channel with various flow conditions. They confirmed that side slopes with seepage were less stable than channels without seepage. Crosta and di Prisco (1999) studied seepage erosion causing liquefaction and rapid slope failures by comparing observed field failure mechanisms and the evolution of the saturated domain using a numerical model. They reported that failure was induced by the three-dimensional development of the saturated domain from a localized source. Hagerty et al. (1981) investigated bank erosion in the Ohio River and concluded that one of the principal erosion mechanisms is internal erosion of bank materials by discharge following floods. Kusakabe et al. (1987) carried out a series of centrifuge model tests to study river bank failures due to seepage flow and found that clay and silt content of river bank material have a significant effect on the importance of seepage flow. Dapporto et al. (2003) investigated the mechanisms of failure and the retreat of the Arno River in Italy using numerical models to predict changes in soil-water pressure and to analyze the stability of the banks due to variation in the river stage. They demonstrated that the complex interaction between soil-water pressure and the stabilizing confining pressures of the river stage play the primary role in triggering mass failures. However, none of these studies included particle mobilization and undercutting of banks due to seepage erosion.

According to Rockwell (2002), the greatest weakness of both seepage and soil-water pressure studies has been the lack of direct, local, and precise instrumentation. Quantitative data are not available at the point of erosion, and quantitative existence of seepage is only known indirectly. This limitation could be due to the difficulty of conducting field studies during wet periods when seepage is active (Huang and Laflen 1996; Wilson et al. 2007). Study of failure due to seepage flow requires accumulated data of close observations on the phenomena in the field as well as laboratory reproduction of these phenomena. This is necessary to understand such physical events and deduce physical models and analytical methods to predict the risk of failure (Kusakabe et al. 1987).

A few studies in the literature have begun to study seepage erosion in the laboratory and field with details suggested by Rockwell (2002). Lourenco et al. (2006) examined the relation between soil-water pressure and the failure mode at the interface of two soil layers of different permeability. Although their experiments did not show any clear relation between soil-water pressure and the failure mode, it demonstrated that seepage strongly controlled the failure mechanisms. Fox et al. (2006) and Wilson et al. (2007) conducted lysimeter experiments on the undercutting of streambanks by seepage flow indicating that seepage undercutting, independent of the loss of negative soil-water pressure, could result in bank collapse. Wilson et al. (2007) documented the first in situ detailed measurements of seepage flow, erosion, and bank undercutting and demonstrated that streambank stratigraphy and layering were important factors of seepage erosion (Fig. 1). Fox et al. (2007) demonstrated that undercutting occurs not only due to seepage through a conductive, noncohesive streambank layer as observed by Wilson et al. (2007), but can also occur when seepage erosion undercuts less cohesive layers underneath the conductive layer.

While studies quantifying the effects of seepage erosion on bank stability are improving, bank stability analysis has not been developed to address the effects of bank undercutting brought about by seepage erosion particle mobilization. Seepage forces have been incorporated into slope stability analyses for homoge-

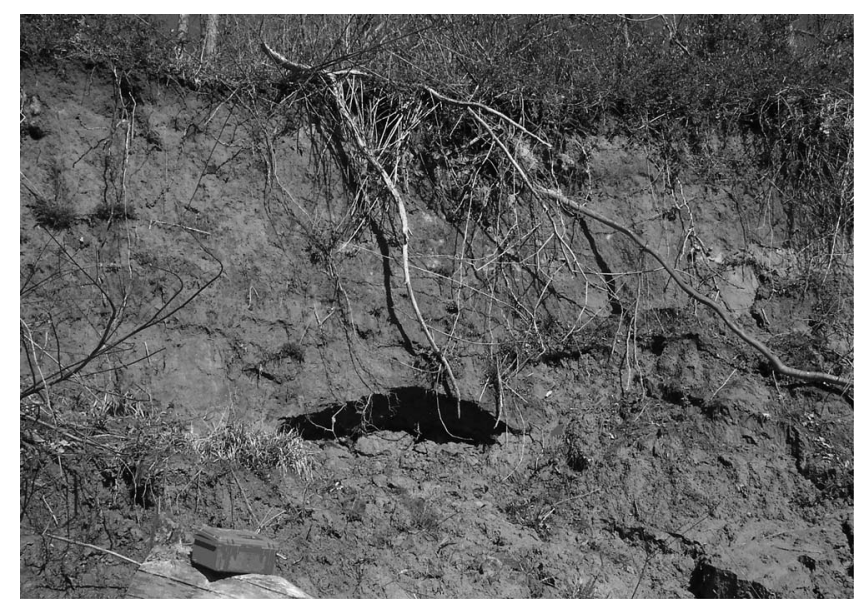

Fig. 1. Example of seepage erosion particle mobilization and undercutting on Little Topashaw Creek streambank in northern Mississippi

neous, isotropic banks to predict cantilever or "popout" failures (Budhu and Gobin 1996), but no slope stability analyses have attempted to incorporate particle mobilization by seepage gradients leading to undercutting on layered bank profiles. Few, if any, studies on seepage have attempted to incorporate bank instability by the combined forces of increased soil-water pressure and seepage undercutting. Wilson et al. (2007) acknowledged the need to incorporate a subsurface flow model with a streambank stability model and suggested that the dynamic process of seepage erosion and undercutting needs to be included in the combined models. Undercutting, primarily considered at this time due to fluvial mechanisms, has been reported to have a major impact on slope failure. What is not known is whether seepage undercutting can lead to distances of undercutting that are a significant cause of instability. This research attempts to answer this question for these experimental conditions to determine if future work should be aimed at incorporating this instability mechanism into streambank stability models.

The objective of this research was to develop a procedure that will quantify the effects of seepage undercutting on bank stability. The two-dimensional lysimeter experiments of Fox et al. (2006) and Wilson et al. (2007) were simulated using a variably saturated flow model integrated with a geotechnical bank stability model. The variably saturated flow model was calibrated based on measured cumulative discharge and soil pore-water pressure. Field measured geotechnical parameters were used without calibration as estimates of lysimeter parameters in the bank stability model. Seepage erosion was simulated by manually changing the geometry of the loamy sand (LS) layer based on available data for the dimensions and shape of the undercutting. Therefore, a priori information on undercutting was used in the model (i.e., no particle dynamics model was used to estimate the headcut formation). This research evaluates bank stability driven by dynamic changes in the streambank face geometry due to seepage undercutting. Undercutting by seepage particle mobilization is analogous to gully erosion processes in that headcuts cause headward migration of internal gullies from the bank face.

\section{Materials and Methods}

\section{Lysimeter Experiments}

Fourteen lysimeter experiments $(1.0 \mathrm{~m}$ long, $0.15 \mathrm{~m}$ wide, and either 0.5 or $1.0 \mathrm{~m}$ tall) were performed by Fox et al. (2006) and 


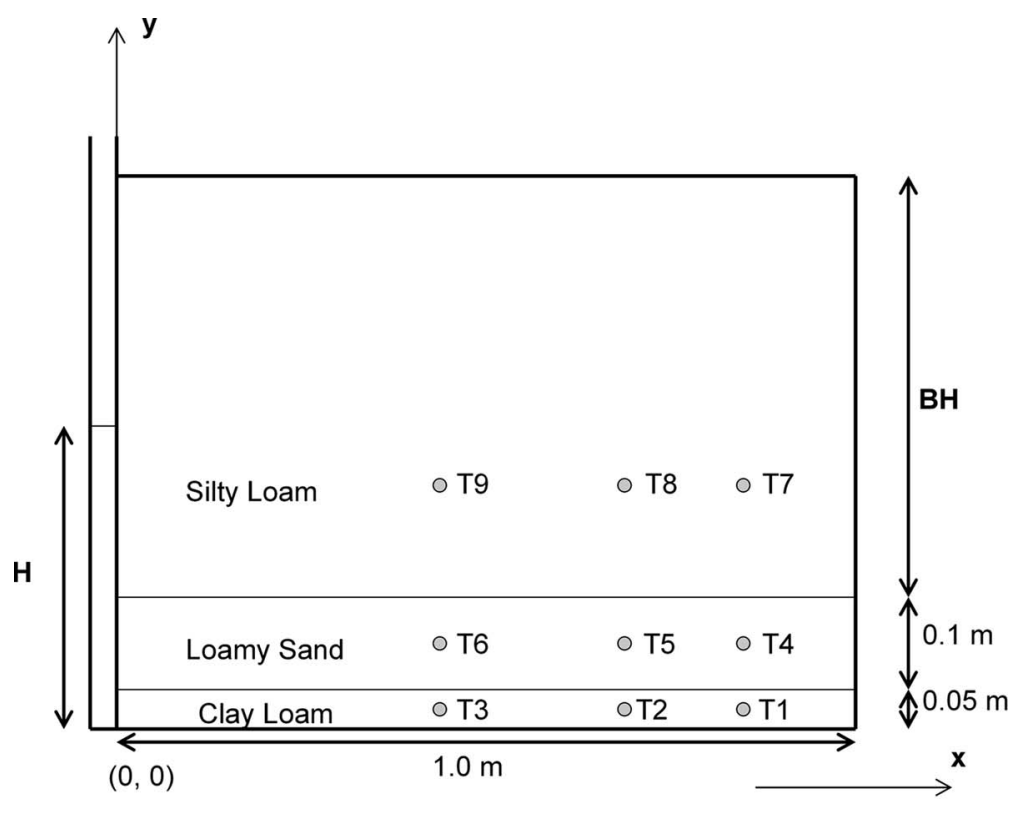

\section{LOCATION OF TENSIOMETERS:}

In the Clay Loam layer:

T1 $(0.85,0.025)$

T2 $(0.70,0.025)$

T3 $(0.40,0.025)$

In the Loamy Sand layer:

T4 $(0.85,0.10)$

T5 $(0.70,0.10)$

T6 $(0.40,0.10)$

In the Silty Loam layer:

$T 7(0.85,0.30)$

T8 $(0.70,0.30)$

T9 $(0.40,0.30)$

Fig. 2. Lysimeter setup showing location of tensiometers and the hydraulic controls of experiment

Wilson et al. (2007) to simulate seepage erosion at Little Topashaw Creek (LTC) in northern Mississippi. The simulated LTC streambanks consisted of a silt loam (SiL) top soil of varying bank height, a $0.10 \mathrm{~m}$ conductive LS layer, and a $0.05 \mathrm{~m}$ clay loam (CL) restrictive layer at the bottom (Fig. 2). Flow through the lysimeter was controlled using constant heads of 0.3 and $0.6 \mathrm{~m}$. The base of the lysimeter was tilted to simulate banks with 0,5 , and $10 \%$ slopes. Of the 14 lysimeter experiments performed, six were selected so that the modeling included various bank heights $(\mathrm{BH})$, heads in the water inflow reservoir $(H)$, and bank slope $(S)$ : BH from 0.3 to $0.8 \mathrm{~m}, \mathrm{H}$ from 0.3 to $0.6 \mathrm{~m}$, and $S$ from 0 to $10 \%$ (Table 1). The simulations also included an experiment where bank failure did not occur despite significant seepage undercutting $(H=0.3 \mathrm{~m}, \mathrm{BH}=0.4 \mathrm{~m}$, and $S=0 \%)$.

Data from the lysimeter experiments included soil-water pressure measured by nine tensiometers (Fig. 2) within the three streambank layers and cumulative discharge measurements at specific times (Periketi 2005; Wilson et al. 2007). During the lysimeter experiments, the depth of seepage undercutting, referred to as the horizontal distance from the drainage face of the lysimeter into the bank, was measured. These measurements were used to simulate seepage undercutting in the bank stability model. Examples of the undercutting by seepage particle mobilization and resulting bank collapses are shown in Fig. 3.

Table 1. Boundary Conditions for Two-Dimensional Seepage Erosion Lysimeter Experiments Simulated Using SEEP/W and SLOPE/W

\begin{tabular}{lcc}
\hline $\begin{array}{l}\text { Constant head, } H \\
(\mathrm{~m})\end{array}$ & $\begin{array}{c}\text { Bank height, BH } \\
(\mathrm{m})\end{array}$ & $\begin{array}{c}\text { Slope, } S \\
(\%)\end{array}$ \\
\hline 0.3 & 0.4 & 0 \\
0.3 & 0.8 & 0 \\
0.6 & 0.8 & 0 \\
0.6 & 0.5 & 5 \\
0.6 & 0.5 & 10 \\
0.6 & 0.8 & 10 \\
\hline
\end{tabular}

\section{Variably Saturated Flow Modeling}

The lysimeter experiment was modeled using SEEP/W to simulate the variations in the soil-water pressure and cumulative discharge. SEEP/W is a finite-element model of Richards' equation for two-dimensional variably saturated flow (Krahn 2004a). The flow domain was constructed to represent the geometry of the lysimeter with five or six internal material regions. The CL layer was considered as one region, the SiL another region, and the conductive LS layer was divided into three or four regions to
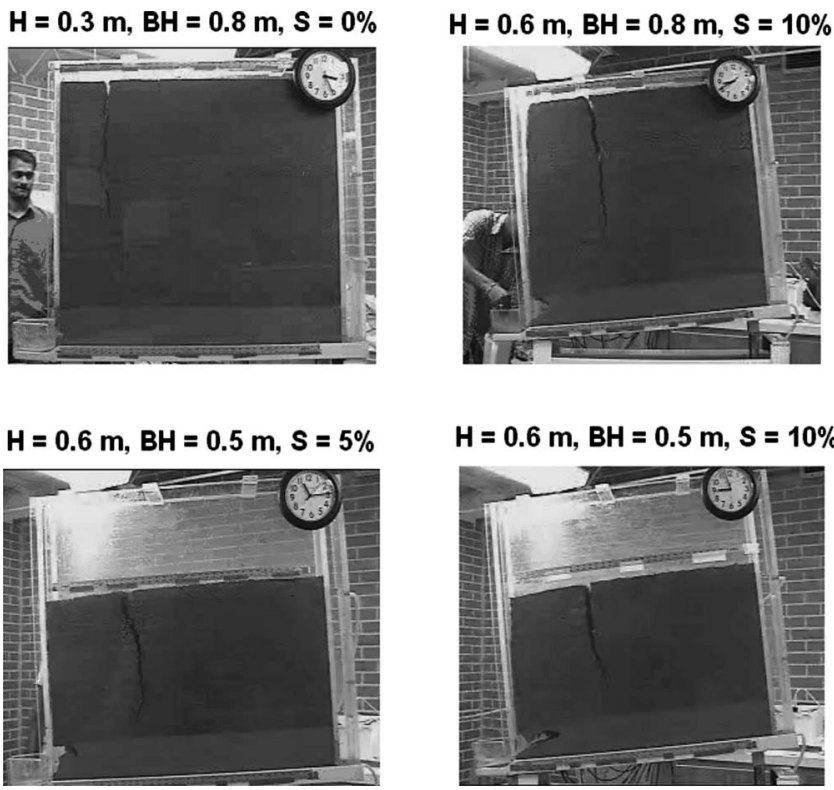

Fig. 3. Examples of undercutting by seepage particle mobilization, tension crack formation, and bank collapse observed during lysimeter experiments 
facilitate the change in the flow domain geometry to account for seepage erosion undercutting the streambank. The regions were then discretized into 25 by $25 \mathrm{~mm}$ elements.

Specifying and assigning material properties in SEEP/W involves defining the water retention function, $\theta(h)$, and the hydraulic conductivity function, $K(h)$, where $h=$ soil-water pressure (Krahn 2004a). It is a common practice to use an estimation method to represent $\theta(h)$ and $K(h)$, such as the van Genuchten (1980) model

$$
\begin{gathered}
\theta(h)=\left\{\begin{array}{cc}
\theta_{r}+\frac{\theta_{s}-\theta_{r}}{\left[1+|\alpha h|^{n}\right]^{m}} & h<0 \\
\theta_{s} & h \geqslant 0
\end{array}\right\} \\
K(h)=K_{s} S_{e}\left[1-\left(1-S_{e}^{1 / m}\right)^{m}\right]^{2} \quad m=1-1 / n, n>1
\end{gathered}
$$

where $S_{e}=\left(\theta-\theta_{r}\right) /\left(\theta_{s}-\theta_{r}\right)=$ effective saturation; $\alpha\left[\mathrm{L}^{-1}\right]$ and $n=$ empirical parameters; $\theta_{s}=$ saturated water content; $\theta_{r}=$ residual water content; and $K_{s}\left[\mathrm{LT}^{-1}\right]=$ saturated hydraulic conductivity.

Laboratory measurements of soil hydraulic properties from undisturbed soil cores were used to define the parameters of the van Genuchten (1980) model. Soil samples were taken from LTC field sites where seepage occurred through the conductive LS layer with a restrictive layer below (Fox et al. 2006; Wilson et al. 2007). These values were used as default soil hydraulic property values prior to calibration. Calibration of the models was carried out in two ways to match the observed hydrologic response (i.e., cumulative discharge and soil pore-water pressure): (1) by adjusting $K_{s}$ of the LS layer (due to the sensitivity of the model relative to this parameter), whereas the van Genuchten parameters $\left(\theta_{s}, \theta_{r}\right.$, $\alpha$, and $n$ ) and $K_{s}$ of other layers were not calibrated; and (2) calibration on the $K_{s}$ and van Genuchten parameters of all soil layers.

SEEP/W uses either Dirichlet or Neuman boundary conditions in which the hydraulic head or the discharge, respectively, is specified at a boundary. If the discharge is specified, SEEP/W will compute the soil-water pressure to maintain the specified discharge and vice versa. The initial conditions of the models were derived from the initial measured soil-water pressure from the lysimeter experiments. A potential seepage review boundary condition for all the nodes was assigned at the drainage face. In SEEP/W, a potential seepage review boundary condition is used when neither the hydraulic head nor the discharge are known beforehand but instead must be computed by the model (Krahn 2004a), as in the case of the drainage from the lysimeter or bank face. A hydraulic boundary function was used as the boundary condition at the inflow face and a zero flux boundary condition was specified for the top and bottom boundaries.

The performance of the SEEP/W models was quantified by using an objective function and by visual comparison of the simulated and measured soil-water pressure and cumulative discharge. Differences between the simulated and observed cumulative discharge values were minimized based on linear regression while also minimizing the root-mean-square error (RMSE) of the simulated and measured soil-water pressure.

\section{Streambank Stability Modeling}

SLOPE/W is a numerical slope stability model which uses the theory of limit equilibrium of forces and moments to compute the $F s$ against failure. It involves discretizing a potential sliding mass into vertical slices and applying equations of statics (Krahn 2004b). A Fs is defined as that factor by which the shear strength

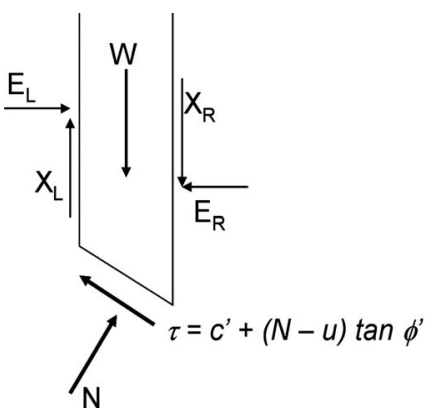

$W=$ Slice weight

$\mathrm{N}=$ Slice base normal force

$\tau=$ Slice base shear force

$c^{\prime}=$ Effective cohesion

$\phi^{\prime}=$ Effective angle of friction

$u=$ soil pore-water pressure

$X$ and $E=$ interslice forces

Fig. 4. Free-body diagram of vertical slice within potential sliding mass and definition of critical variables

of the soil must be reduced in order to bring the mass of soil into a state of limiting equilibrium along a selected slip surface (Fig. 4). The $F s$ is an index of the relative stability of a slope.

SLOPE/W was used to analyze the stability of the streambank as simulated by the lysimeter experiments. The stability modeling procedure had three components: (1) definition of the geometry and shape of the potential slip surface; (2) definition of the soil strength properties; and (3) definition of the soil-water pressure. SEEP/W and SLOPE/W are integrated codes such that the geometry defined in SEEP/W is used in SLOPE/W. Soil strength parameters in the lysimeter experiment were defined using Coulomb's equation. For an effective stress analysis, the shear strength is defined as

$$
s=c^{\prime}+\left(\sigma_{n}-u\right) \tan \phi^{\prime}
$$

where $s=$ shear strength; $c^{\prime}=$ effective cohesion; $\phi \prime=$ effective angle of internal friction; $\sigma_{n}=$ total normal stress; and $u=$ soilwater pressure (Krahn 2004b).

The Morgenstern-Price (1965) method was selected for computing Fs. This method satisfies both the moment and force equilibrium equations and can give accurate results for all practical conditions (Duncan and Wright 1980; Krahn 2004b). The general limit equilibrium method uses the relationship proposed by Morgenstern and Price (1965) which is

$$
X=E \lambda f(x)
$$

where $f(x)=$ specified function; $\lambda=$ percentage of the specified function; $E=$ interslice normal force; and $X_{R}$ and $X_{L}=$ interslice shear forces on either side of a slice. The general limit equilibrium method then uses the following equations of statics to solve for the $F s$, where $W=$ slice weight; $D=$ line load; $\beta, R, x, f, d$, and $\omega=$ geometric parameters; and $\alpha^{\prime}=$ inclination of the base:

1. The summation of forces in a horizontal direction for each slice is used to compute the interslice normal force, $E$ [Eq. (4)]. This equation is applied in an integration manner across the sliding mass (i.e., from left to right).

2. The summation of forces in a vertical direction for each slice is used to compute the normal force at the base of the slice, $N$, where $F=$ either moment or force equilibrium factor of safety

$$
N=\frac{W+\left(X_{R}-X_{L}\right)-\frac{c^{\prime} \beta \sin \alpha^{\prime}+u \beta \sin \alpha^{\prime} \tan \phi^{\prime}}{F}}{\cos \alpha^{\prime}+\frac{\sin \alpha^{\prime} \tan \phi^{\prime}}{F}}
$$


Table 2. Soil Strength Parameters of Little Topashaw Creek Streambank Based on Measurements at Two Sites Where Seepage Erosion Was Observed

\begin{tabular}{lcccc}
\hline Layer & $\begin{array}{c}\text { Depth } \\
(\mathrm{m})\end{array}$ & $\begin{array}{c}\text { Cohesion } \\
(\mathrm{kPa})\end{array}$ & $\begin{array}{c}\text { Angle of } \\
\text { internal friction } \\
(\text { degrees })\end{array}$ & $\begin{array}{c}\text { Total unit } \\
\text { weight } \\
\left(\mathrm{kN} / \mathrm{m}^{3}\right)\end{array}$ \\
\hline Silt loam (SiL) & 0.5 & $\begin{array}{c}7.5 \\
(5.0,10.0)\end{array}$ & $\begin{array}{c}30.0 \\
(25.0,35.0)\end{array}$ & 16.0 \\
Loamy sand (LS) & 1.5 & $\begin{array}{c}1.0 \\
(1.0,1.0)\end{array}$ & $\begin{array}{c}25.5 \\
(22.0,29.0)\end{array}$ & 19.0 \\
Clay loam (CL) & 2 & $\begin{array}{c}15.0 \\
(15.0)\end{array}$ & $\begin{array}{c}35.0 \\
(35.0)\end{array}$ & 21.0 \\
\hline
\end{tabular}

Note: Values for cohesion and angle of internal friction are average values used in the SLOPE/W model. Parameter values in parentheses are values from each site.

3. The summation of moments about a common point for all slices can be rearranged and solved for the moment equilibrium factor of safety, $\mathrm{Fm}$

$$
F m=\frac{\Sigma\left(c^{\prime} \beta R+(N-u) R \tan \phi^{\prime}\right)}{\Sigma W-\Sigma N f \pm \Sigma D d}
$$

4. The summation of forces in a horizontal direction for all slices gives rise to a force equilibrium factor of safety, $F s$

$$
F s=\frac{\sum\left(\left(c^{\prime} \beta \cos \alpha^{\prime}+(N-u \beta) \tan \phi^{\prime} \cos \alpha^{\prime}\right)\right.}{\sum N \sin \alpha^{\prime}-\Sigma D \cos \omega}
$$

where $F=F m$ when $N$ is substituted into Eq. (6) and $F=F s$ when $N$ is substituted into Eq. (7). The relationship between the interslice normal force $(E)$ and the interslice shear force $(X)$ were both considered and the interslice function was derived from a half-sine function.

The soil-water pressure distribution generated from SEEP/W was input into SLOPE/W. The model was then run using the soil-water pressure at every time step to determine the effect of the changes on the stability of the slip surface. The auto-search option was chosen for defining the potential slip surface. In this method, SLOPE/W generated 1,000 trial slip surfaces to find the most probable minimum slip surface based on the problem's geometry by identifying the most probable entry and exit areas of the slip surface. This method can result in unrealistic slip outputs so that comparison of the generated slip surface with the actual appearance of the collapsed bank is necessary.

For each lysimeter experiment, a probabilistic slope stability approach of solving the $F s$ was adopted by considering the variability of the soil strength parameters of the SiL and LS layers. SLOPE/W can perform a probabilistic slope stability analysis which allows for the consideration of variability in input parameters (Krahn 2004b). The user can assign a probability-density function (PDF) to input parameters (Caviness et al. 2006). Using the specified PDF, SLOPE/W derives the cumulative distribution function by integrating the area under the PDF. The cumulative distribution function is then inverted to produce the sampling function. Each time a random number is generated from the Monte Carlo method, the parameter is "sampled" using this function. The randomly generated parameter is then fed into the deterministic model to compute the $F s$.

Field measurements of cohesion, angle of internal friction, and total unit weight from the LTC streambank site where the lysimeter soil was sampled were carried out using a borehole shear test at two field locations. Average soil strength values (Table 2) were used to define the material properties of the layers for the slope stability model. The variability in these soil strength parameters was assumed to follow a normal probability density function similar to most geotechnical engineering material properties (Krahn 2004b). A standard deviation equal to 2.0 was chosen and 2,000 Monte Carlo trials were simulated as suggested by Krahn (2004b).

The unavailability of models to simulate undercutting, which modifies the flow domain with time, makes it difficult to quantify the importance of seepage erosion in slope stability analysis. SEEP/W uses a finite-element method that requires the elements to be connected at the corners by nodes which is not representative of an undercutting process where the elements tend to "break away" from the adjacent elements. SLOPE/W, on the other hand, being a limit equilibrium program, cannot model overhanging walls or undercut slopes where the base of some slices are exposed to the air. This is the case of undercutting brought about by seepage erosion. In order to overcome these limitations, a procedure was developed to incorporate the effects of undercutting into the variably saturated flow stability models.

For the lysimeter experiments, seepage erosion was simulated by manually changing the geometry of the LS layer based on available data for the dimensions and shape of the undercutting. The shape, dimensions, and timing of undercutting were measured during the lysimeter experiment as reported by Periketi (2005) and Wilson et al. (2007). From this information, seepage erosion was modeled by dividing the LS layer into segments. Changes in the geometry of the domain to reflect the shape and location of the undercutting (e.g., Fig. 5) was accomplished by changing the material properties of segments. SLOPE/W's limitation regarding undercutting was addressed by covering the cut with a null region without specifying any soil strength properties. In SEEP/W, this region was treated as a void in the flow domain by not assigning a material property (Fig. 5). This will exclude the weight of the null region in the analysis. The performance of the SLOPE/W models in predicting the shape of the critical slip surface was evaluated by comparing the measured dimensions of the collapsed bank against the critical slip surface generated by the model.

\section{Results and Discussion}

Calibrated values of LS layer $K_{s}$ (i.e., $180.0-632.0 \mathrm{~cm} /$ day) in each SEEP/W lysimeter model varied from the field-measured average value (i.e., $1,453.1 \mathrm{~cm} /$ day) reported by Fox et al. (2006) and Wilson et al. (2007) (Table 3). RMSEs between observed and predicted soil-water pressure are outlined in Table 4 and results of the linear regression between predicted and measured cumulative discharge are outlined in Table 5 for two cases: (1) prior to calibration; and (2) after calibration on the LS $K_{s}$. Tensiometer 8 in the SiL layer of the $0.8 \mathrm{~m} \mathrm{BH}, 0 \% \mathrm{~S}$, and 0.3 and $0.6 \mathrm{~m} \mathrm{H}$ experiments did not operate properly during the experiments and was not considered in the calibration process. Simply calibrating on the LS $K_{s}$ provided a reasonable fit (i.e., maximum RMSE of 0.13 ) in terms of soil pore-water pressure compared to calibration on $K_{s}$ and water retention parameters of all soil layers (i.e., maximum RMSE of 0.11). It is this pore-water pressure distribution which is critical for the SLOPE/W stability software. The benefit of calibration on the $K_{s}$ of other layers and water retention parameters was in regard to prediction of cumulative discharge as quantified through the slope and $R^{2}$ of the linear regression (Table 5, Fig. 6). However, this improved fit required the use of unrealistic values for the van Genuchten parameters in the LS layer. 
(a)

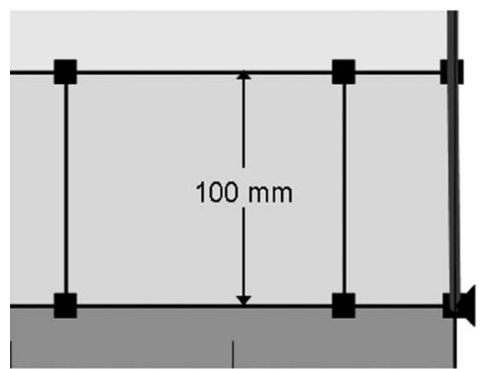

SEGMENT 1 (0-195 s)

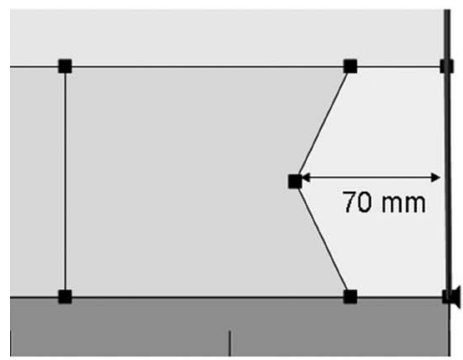

SEGMENT 4 (360-435 s)

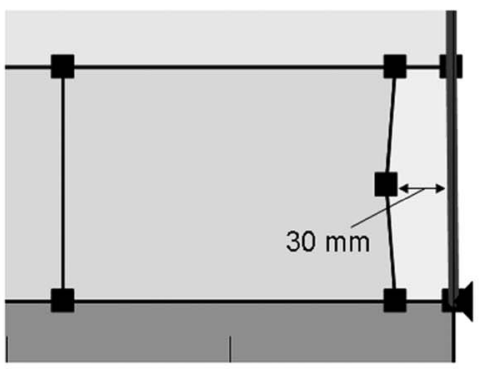

SEGMENT 2 (210-225 s)

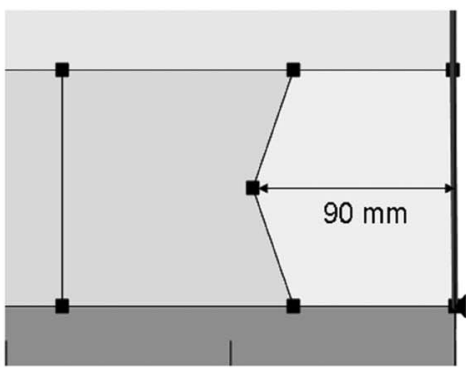

SEGMENT 4 (450-465 s)

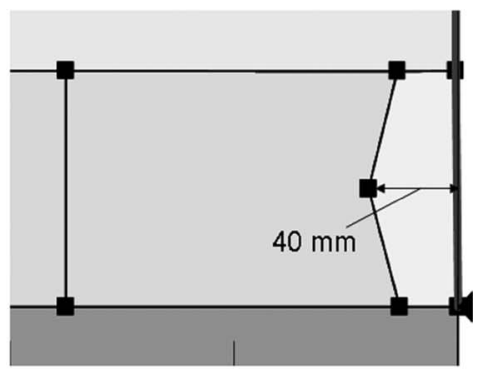

SEGMENT 3 (240-345 s)

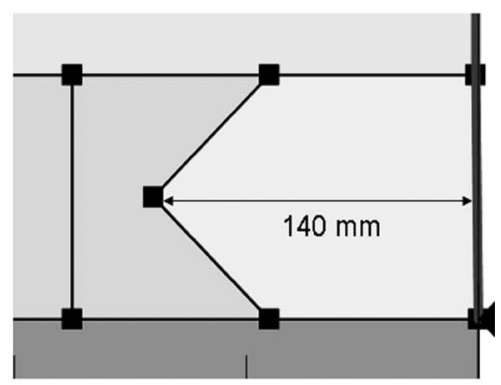

SEGMENT 5 (480-570 s)

(b)

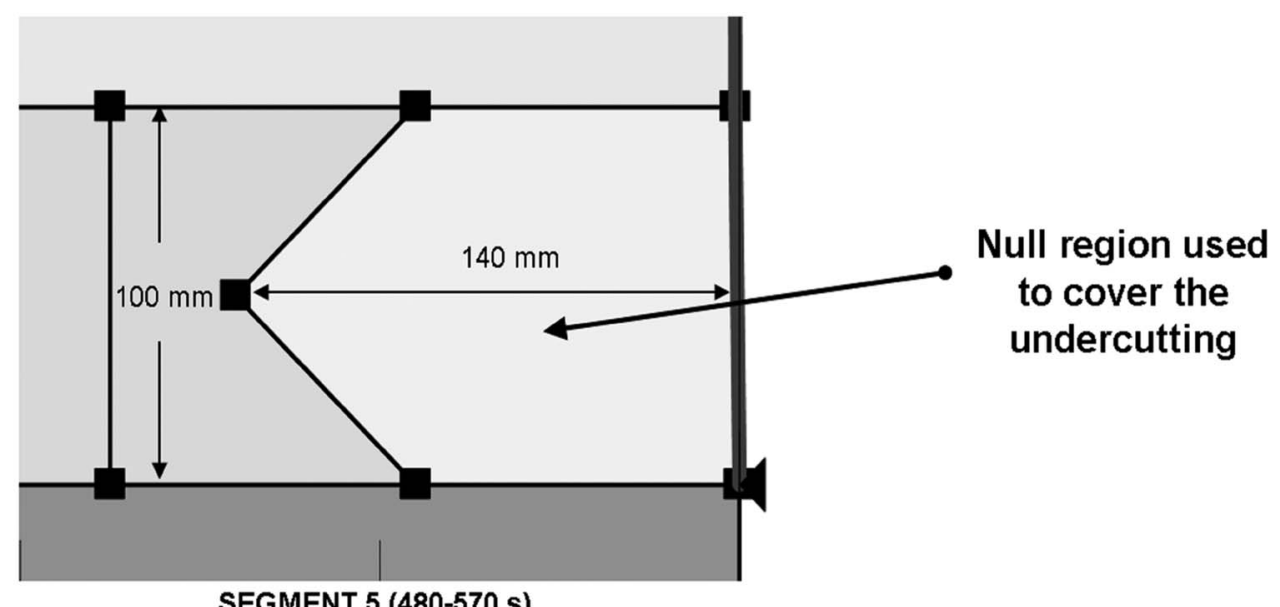

Fig. 5. (a) Change in geometry in SLOPE/W modeling of loamy sand layer experiencing undercutting by seepage erosion; (b) null region used in place of seepage undercut in SLOPE/W model. Figures shown are for experiment with $0.6 \mathrm{~m}$ constant head, $0.8 \mathrm{~m}$ bank, and $0 \%$ slope.

Soil-water pressure generated from SEEP/W at specific time steps were used to define the input soil-water pressure in SLOPE/W. The predicted, mean $F s$ when undercutting was not considered, (Fig. 7) did not significantly change during any of the lysimeter simulations. Changes in soil-water pressure did not sufficiently affect soil strength in these experiments and therefore did not reduce the stability of the bank. Yet it is the impact of soilwater pressure on soil strength that is most often attributed to bank failure (e.g., Burgi and Karaki 1971; Edil and Vallejo 1980; Darby and Thorne 1996; Abam 1993; Crosta and Prisco 1999; Rinaldi and Casagli 1999; Simon et al. 1999; Dapporto et al. 2003). In contrast to the impact of soil-water pressure, the Fs decreased approximately $42 \%$ (from a mean value of $1.06-0.62$ ) and $55 \%$ (from a mean value of $1.05-0.47$ ) for experiments with 0.3 and $0.6 \mathrm{~m} H(0.8 \mathrm{~m} \mathrm{BH}$ and $0 \% S)$, respectively, when seepage particle mobilization and undercutting was considered (Fig. 7). This resulted in an unstable bank (i.e., $F_{s}<1.0$ ) at the end of the simulation. Experiments with greater than $0 \%$ slope were predicted to be unstable at the beginning of the simulation based on the mean $F s(F s<1.0)$. The $F s$ for these experiments decreased $50-91 \%$ between simulations when seepage undercutting was included.

For stable banks with sufficient undercutting measurements (i.e., $0.8 \mathrm{~m} \mathrm{BH}, 0 \% \mathrm{~S}$ ), the change in the probability of failure, or 
Table 3. Field Measured Hydraulic Conductivity, $K_{s}$, and Soil-Water Retention Parameters of Little Topashaw Creek Streambank Sediment and Comparison to Calibrated LS Layer $K_{s}$ for Lysimeter Experiments; SEEP/W Model Was Most Sensitive to This Parameter; Therefore, All Other Parameters Were Not Part of Model Calibration

\begin{tabular}{ccccc}
$\begin{array}{c}\text { Soil } \\
\text { layer }\end{array}$ & $\begin{array}{c}K_{s} \\
(\mathrm{~cm} / \text { day })\end{array}$ & $\begin{array}{c}\theta_{\mathrm{s}} \\
\left(\mathrm{cm}^{3} \mathrm{~cm}^{-3}\right)\end{array}$ & $\begin{array}{c}\alpha \\
(\mathrm{kPa})\end{array}$ & $n$ \\
\hline
\end{tabular}

Field measured parameters

$\begin{array}{lrlll}\text { SiL } & 63.9 & 0.39 & 4.9 & 3.5 \\ \text { LS } & 1,453.1 & 0.40 & 2.5 & 3.0 \\ \text { CL } & 5.4 & 0.44 & 9.8 & 1.7\end{array}$

Calibrated $K_{s}$ for LS layer in the lysimeter

$H=0.3 \mathrm{~m}, \mathrm{BH}=0.4 \mathrm{~m}, S=0 \%$

$H=0.3 \mathrm{~m}, \mathrm{BH}=0.8 \mathrm{~m}, S=0 \%$

$H=0.6 \mathrm{~m}, \mathrm{BH}=0.8 \mathrm{~m}, S=0 \%$

$H=0.6 \mathrm{~m}, \mathrm{BH}=0.5 \mathrm{~m}, S=5 \%$

$H=0.6 \mathrm{~m}, \mathrm{BH}=0.5 \mathrm{~m}, S=10 \%$

LS $\quad 180.0$

LS $\quad 628.0$

LS $\quad 632.0$

LS $\quad 556.0$

$H=0.6 \mathrm{~m}, \mathrm{BH}=0.8 \mathrm{~m}, S=10 \%$

LS

363.0

Note: $\theta_{s}=$ Saturated water content; $d$ and $n=$ empirical parameters; SiL=silt loam; LS=loamy sand, $\mathrm{CL}=$ clay clay loam; $H=$ constant inflow water reservoir head; $\mathrm{BH}=$ bank height; and $S=$ slope.

risk of instability, predicted by the modeling, increased from 35.2 to $100 \%$ for $H=0.3 \mathrm{~m}$ and from 36.5 to $100 \%$ for $H=0.6 \mathrm{~m}$ when seepage undercutting became active (Fig. 8). The probability of failure is determined by counting the number of $F s$ values less than 1.0 with respect to the total number of Monte Carlo trails. It is equivalent to the percentage of slopes that would fail if a slope were to be constructed repeatedly. A probability of failure equal to $100 \%$ was reached when the depth of undercutting reached approximately $30-50 \mathrm{~mm}$ into the bank for this specific streambank profile. Since the parameters used in the simulation with and without seepage erosion were the same, the increase in the probability of failure and decrease in the $F s$ can be attributed to the change in the geometry of the LS layer due to simulated undercutting by seepage erosion. The results also show that a stable bank (i.e., $F s>1.0$ ) can become significantly unstable when seepage erosion is considered.
The SLOPE/W model consistently predicted failure ahead of the observed bank collapse (i.e., a $100 \%$ probability of failure was reached before the actual collapse observed during the lysimeter experiments). For example, SLOPE/W predicted collapse approximately 300-500 s before actual bank collapse for the lysimeter experiments with 0.3 and $0.6 H(0.8 \mathrm{~m} \mathrm{BH}$ and $0 \% S)$. For the experiment where bank failure did not occur due to seepage undercutting $(H=0.3 \mathrm{~m}, \mathrm{BH}=0.4 \mathrm{~m}$, and $S=0 \%)$, the model predicted a bank collapse of $0.05 \mathrm{~m}^{3}$. This is an indication that the lysimeter setup is more stable than the bank simulated by the model. This condition can be due to three factors. First, the geotechnical parameters were simulated using field measurements as opposed to soil parameter testing of the repacked lysimeter soil. Second, the walls of the lysimeter (only separated by $15 \mathrm{~cm}$ ) may have induced compressive forces to counteract stresses produced by the soil weight. Also, uniform packing of disturbed soil

Table 4. Root-Mean-Square Error (RMSE) of Measured and SEEP/W Simulated Soil-Water Pressure for Tensiometers in Each Lysimeter Experiment before Calibration and after Calibration on Saturated Hydraulic Conductivity, $K_{s}$, of LS Layer

\begin{tabular}{|c|c|c|c|c|c|c|c|c|c|c|c|}
\hline \multicolumn{3}{|c|}{ Lysimeter experiment } & \multicolumn{9}{|c|}{ Tensiometers } \\
\hline $\begin{array}{l}\text { Head } \\
(\mathrm{m})\end{array}$ & $\begin{array}{l}\text { Bank } \\
\text { height } \\
(\mathrm{m})\end{array}$ & $\begin{array}{c}\text { Slope } \\
(\%)\end{array}$ & 1 & 2 & 3 & 4 & 5 & 6 & 7 & 8 & 9 \\
\hline \multicolumn{12}{|c|}{ (a) Prior to calibration } \\
\hline 0.3 & 0.4 & 0 & 0.17 & 0.08 & 0.08 & 0.07 & 0.08 & 0.11 & 0.08 & 0.06 & 0.01 \\
\hline 0.3 & 0.8 & 0 & 0.06 & 0.06 & 0.07 & 0.01 & 0.01 & 0.04 & 0.03 & - & 0.04 \\
\hline 0.6 & 0.8 & 0 & 0.11 & 0.07 & 0.21 & 0.02 & 0.02 & 0.06 & 0.05 & - & 0.09 \\
\hline 0.6 & 0.5 & 5 & 0.04 & 0.06 & 0.21 & 0.04 & 0.04 & 0.04 & 0.03 & 0.06 & 0.08 \\
\hline 0.6 & 0.5 & 10 & 0.03 & 0.01 & 0.21 & 0.06 & 0.06 & 0.05 & 0.05 & 0.08 & 0.10 \\
\hline 0.6 & 0.8 & 10 & 0.03 & 0.01 & 0.15 & 0.04 & 0.06 & 0.06 & 0.04 & 0.09 & 0.09 \\
\hline \multicolumn{12}{|c|}{ (b) Calibration on $K_{s}$ of LS } \\
\hline 0.3 & 0.4 & 0 & 0.04 & 0.02 & 0.03 & 0.06 & 0.02 & 0.10 & 0.03 & 0.02 & 0.03 \\
\hline 0.3 & 0.8 & 0 & 0.04 & 0.03 & 0.04 & 0.03 & 0.04 & 0.03 & 0.03 & - & 0.06 \\
\hline 0.6 & 0.8 & 0 & 0.07 & 0.01 & 0.13 & 0.04 & 0.07 & 0.05 & 0.04 & - & 0.11 \\
\hline 0.6 & 0.5 & 5 & 0.03 & 0.02 & 0.10 & 0.05 & 0.10 & 0.10 & 0.02 & 0.06 & 0.08 \\
\hline 0.6 & 0.5 & 10 & 0.03 & 0.03 & 0.05 & 0.06 & 0.10 & 0.11 & 0.02 & 0.03 & 0.08 \\
\hline 0.6 & 0.8 & 10 & 0.03 & 0.03 & 0.04 & 0.05 & 0.11 & 0.12 & 0.03 & 0.05 & 0.07 \\
\hline
\end{tabular}

Note: The location of tensiometers Nos. 1-9 is depicted in Fig. 1. 
Table 5. Regression between Measured and SEEP/W Simulated Cumulative Discharge in Each Lysimeter Experiment prior to Calibration and after Calibration on Saturated Hydraulic Conductivity, $K_{s}$, of LS Layer

\begin{tabular}{|c|c|c|c|c|c|}
\hline $\begin{array}{l}\text { Head } \\
(\mathrm{m})\end{array}$ & $\begin{array}{l}\text { Bank height } \\
\text { (m) }\end{array}$ & $\begin{array}{c}\text { Slope } \\
(\%)\end{array}$ & $\begin{array}{l}\text { Regression } \\
\text { line slope }\end{array}$ & $\begin{array}{l}\text { Regression } \\
\text { line intercept } \\
\quad\left(\mathrm{m}^{3}\right)\end{array}$ & $R^{2}$ \\
\hline \multicolumn{6}{|c|}{ (a) Prior to calibration } \\
\hline 0.3 & 0.4 & 0 & 25.02 & $1.11 \mathrm{E}-03$ & 0.98 \\
\hline 0.3 & 0.8 & 0 & 5.17 & $2.17 \mathrm{E}-04$ & 0.91 \\
\hline 0.6 & 0.8 & 0 & 5.52 & $1.07 \mathrm{E}-04$ & 0.97 \\
\hline 0.6 & 0.5 & 5 & 5.02 & $3.13 \mathrm{E}-04$ & 0.99 \\
\hline 0.6 & 0.5 & 10 & 9.62 & $3.88 \mathrm{E}-04$ & 0.99 \\
\hline 0.6 & 0.8 & 10 & 5.51 & $1.23 \mathrm{E}-04$ & 0.99 \\
\hline \multicolumn{6}{|c|}{ (b) Calibration on $K_{s}$ of LS } \\
\hline 0.3 & 0.4 & 0 & 1.00 & $-8.01 \mathrm{E}-05$ & 0.82 \\
\hline 0.3 & 0.8 & 0 & 1.12 & $-3.21 \mathrm{E}-05$ & 0.99 \\
\hline 0.6 & 0.8 & 0 & 1.13 & $-6.72 \mathrm{E}-05$ & 0.97 \\
\hline 0.6 & 0.5 & 5 & 1.08 & $-1.62 \mathrm{E}-04$ & 0.95 \\
\hline 0.6 & 0.5 & 10 & 1.05 & $-1.46 \mathrm{E}-04$ & 0.91 \\
\hline 0.6 & 0.8 & 10 & 1.08 & $-1.13 \mathrm{E}-04$ & 0.88 \\
\hline
\end{tabular}

samples can add extra strength to the bank relative to natural field heterogeneity. Even with these experimental conditions, the model predictions of bank collapses were generally within $33 \%$ of the measured volume of bank collapse (Table 6, Fig. 9).

The depth of undercutting and the corresponding mean $F s$ were evaluated by grouping the six experiments into four categories. The minimum and maximum values of the $F s$ were also determined. The first category consists of experiments with the same $\mathrm{BH}$ and $S$ but different $H$. As theoretically expected, these experiments possess the same initial stability. However, as time increased, the bank with higher $H$ had lower $F s$ at a given time due to the fact that the higher $H$ resulted in more rapid undercutting of the bank by seepage erosion. However, the same depth of undercutting resulted in approximately the same bank stability or mean Fs (Fig. 10).

The second category consists of experiments with the same $H$ and $S$ but different $\mathrm{BH}$, which possess different initial bank stabilities: the bank with $\mathrm{BH}=0.4 \mathrm{~m}$ was initially $39 \%$ more stable than $\mathrm{BH}=0.8 \mathrm{~m}$. As undercutting progressed, the stability of both banks converged to approximately the same range, followed by the lower bank $(\mathrm{BH}=0.4 \mathrm{~m})$ having less stability than the higher bank $(\mathrm{BH}=0.8 \mathrm{~m})$ for depths of undercutting greater than $50 \mathrm{~cm}$ (Fig. 11). This crossover in the Fs was hypothesized to be due to the difference in initial conditions between the $\mathrm{BH}=0.4 \mathrm{~m}$ (i.e., initially lower soil-water content) and $\mathrm{BH}=0.8 \mathrm{~m}$ (i.e., initially at field capacity) experiments. Flow arrival at the bank face was delayed for the $\mathrm{BH}=0.4 \mathrm{~m}$ experiment as compared to the $\mathrm{BH}=0.8 \mathrm{~m}$ experiment and the experiment duration was greater (i.e., 2,500 s as opposed to 1,000 s), as demonstrated in Fig. 6. A longer experimental duration corresponded to greater soil water movement into the upper topsoil layer (i.e., SiL) for the $\mathrm{BH}=0.4 \mathrm{~m}$ experiment, which reduced the $F s$ more quickly than in the $\mathrm{BH}=0.8 \mathrm{~m}$ experiment relative to the depth of undercutting.

The third and fourth categories consist of experiments with the same $H$ and $\mathrm{BH}$ but different $S$, with the differences in $S$ affecting the initial stability of the banks. Banks with a 5 and $10 \% S$ were initially unstable $(F s<1.0)$. The difference in the mean $F s$ was approximately the same for all depths of undercutting. However, the difference between the minimum and maximum values tended to decrease as the slope increased (Fig. 12).

Comparison of the different hydraulic controls of the lysimeter experiments showed that the initial stability of the bank was controlled by the $\mathrm{BH}$ and the $S$ of the bank. This reflects the basis of the equations used for limit equilibrium; i.e., bank stability when undercutting is not considered as a function of the geometry of the bank and the soil strength parameters. The size of undercutting and the change in the mean $F s$ resulting from seepage were controlled by $H$. Regardless of the initial stability of the bank, stability quickly converged as undercutting progressed. This convergence made it possible to fit a curve to the model predicted $F s$ for all six lysimeter experiments that suggested an exponential relationship between the depth of undercutting and the mean factor of safety (Fig. 13). The regression parameters are specific to these lysimeter streambank profiles; however, the observed exponential relationship is hypothesized to occur for comparable streambank profiles influenced by seepage undercutting: the Fs decreases exponentially with distance of undercutting by seepage particle mobilization.

\section{Summary and Conclusions}

This research demonstrated a procedure for incorporating seepage particle mobilization and undercutting into bank stability models using data from two-dimensional soil lysimeter experiments of layered streambanks. Changes in soil-water pressure were simulated using SEEP/W, a variably saturated numerical flow model, while bank stability was analyzed using SLOPE/W based on limit equilibrium. Undercutting was mimicked by manually changing the geometry of the flow domain for the conductive layer based on the measured dimensions, shape, and timing of the undercutting due to seepage erosion. The mean $F s$ was used as an index of bank stability for all experiments.

Changes in soil strength, in response to soil-water pressure changes during seepage, were not sufficient to contribute to bank 

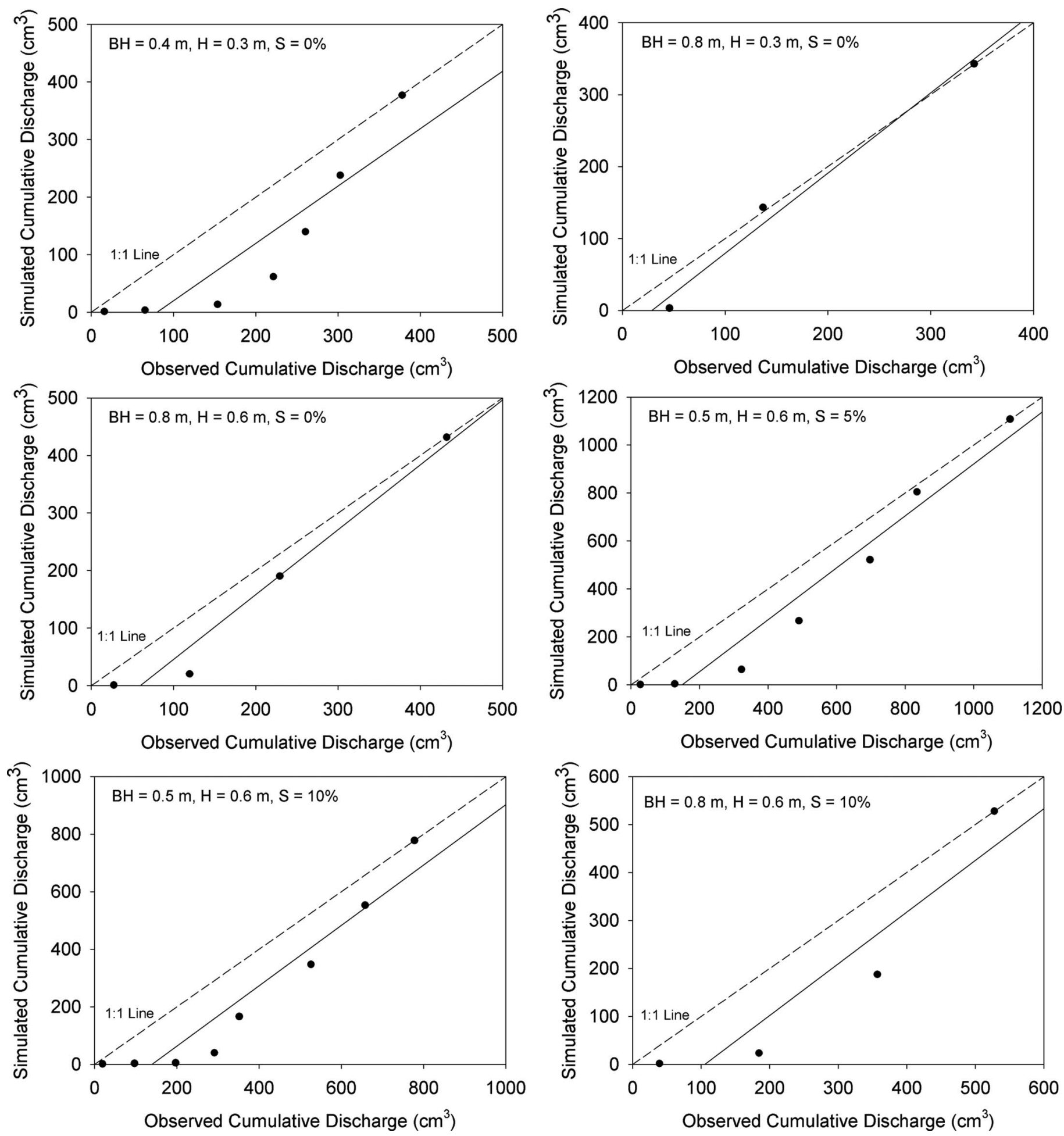

Fig. 6. Observed versus SEEP/W predicted cumulative discharge for six lysimeter experiments after calibration on hydraulic conductivity $\left(K_{s}\right)$ of loamy sand layer. $K_{s}$ and soil-water retention parameters $\left(\theta_{s}, \alpha\right.$, and $\left.n\right)$ were not calibrated for other soil layers.

instability, yet the mean $F s$ decreased significantly as the depth of undercutting increased. The decrease in the mean Fs due to undercutting was in the range of $42-91 \%$ depending on the initial stability of the bank. Regardless of the initial stability of the bank, instability converged as undercutting progressed. This means that a stable bank can quickly become unstable when seepage undercutting is considered. For stable banks, the probability of failure reached $100 \%$ when the depth of the undercutting reached ap- proximately $30-50 \mathrm{~mm}$ for these experimental conditions. Bank height and bank slope controlled the initial stability of the bank while the established constant head controlled the depth of undercutting and the mean $F s$ as undercutting progressed. Based on the results of the lysimeter experiments, the mean $F s$ is exponentially related to the depth of undercutting.

Prior to this work, undercutting was primarily considered from a fluvial process perspective. In situ measurements of seepage 

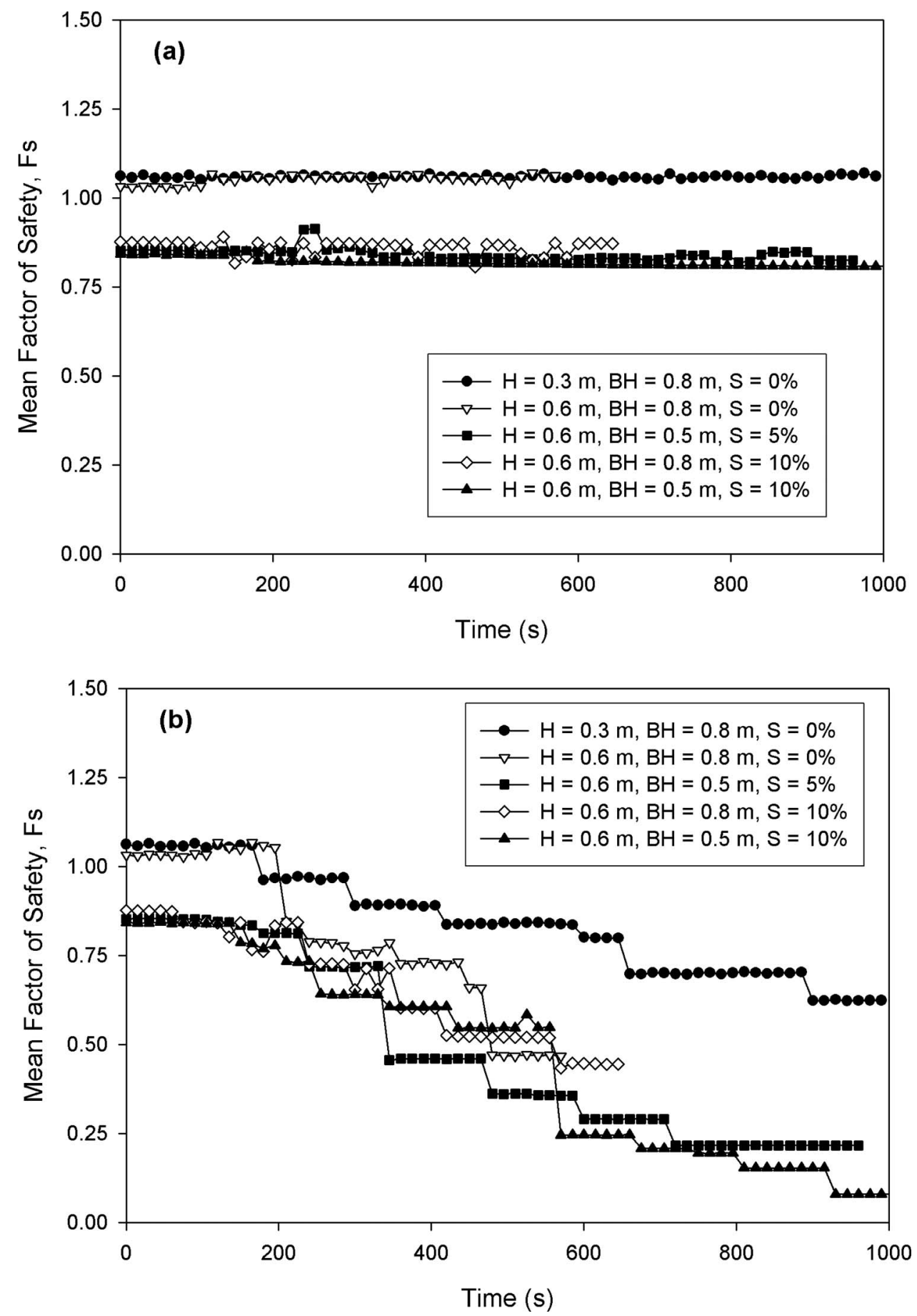

Fig. 7. Mean factor of safety $(F s)$ versus time as predicted by SLOPE/W Monte Carlo analysis for lysimeter experiments: (a) without considering seepage undercutting; (b) with seepage undercutting

erosion documented that undercutting occurs by seepage erosion independent of the fluvial process and these findings, along with measurements of streambank physical properties, guided laboratory experiments of seepage erosion for a range of hydrologic conditions. This work is unique in that these experiments were used to calibrate a variably saturated flow model integrated with a geotechnical slope stability model that simulated undercutting due to seepage erosion based upon field measurements of the geotechnical properties without calibration but with stochastic sampling of the properties probability density function. The numerical modeling showed that seepage erosion can lead to distances of undercutting that are a significant cause of bank instability. The loss of supporting material brought about by seepage particle mobilization and undercutting can be a major cause of slope instability and may be of equal or greater importance than the impact of increased soil-water pressure on soil strength for such streambank conditions.

Future work should be aimed at incorporating this instability mechanism into streambank stability models. The difficulty with current models is the need to know a priori the distance of seepage undercutting. Future work should establish relationships between the volume and shape of undercutting with seepage flow 

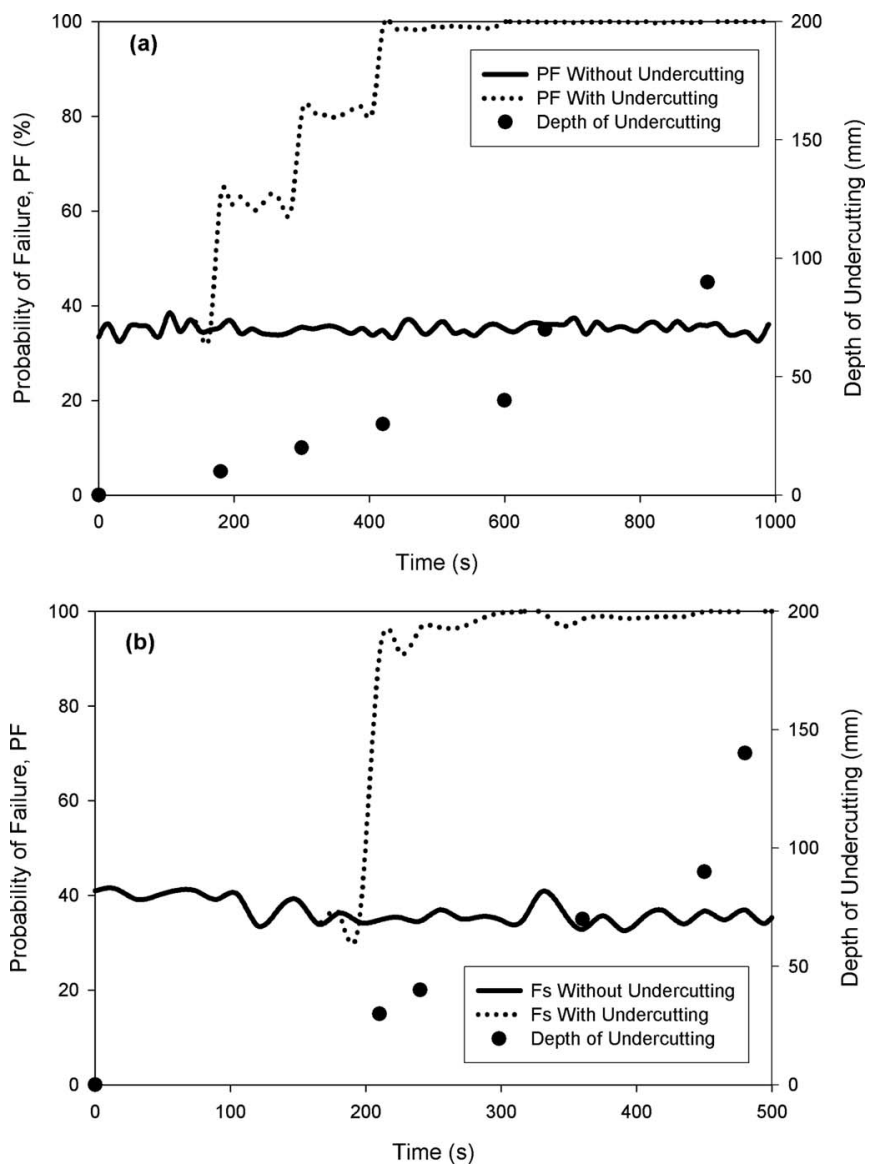

Fig. 8. Simulated probability of failure (PF) (\%) of lysimeter experiments with $0.8 \mathrm{~m}$ bank, $0 \%$ slope, and: (a) $0.3 \mathrm{~m}$ constant head; (b) $0.6 \mathrm{~m}$ constant head with and without seepage undercutting

velocity under a variety of hydrologic conditions and soil properties such that a sediment transport equation can be added into the bank stability model to provide predictive capabilities without a priori knowledge of the undercutting.

\section{Acknowledgments}

This material is based upon work supported by the Cooperative State Research, Education, and Extension Service, U.S. Department of Agriculture, under Award No. 2005-35102-17209.

Table 6. Comparison of Observed versus SLOPE/W Predicted Volume of Bank Collapse

\begin{tabular}{lccccc}
\hline & \multicolumn{5}{c}{$\begin{array}{c}\text { Volume of } \\
\text { collapsed bank } \\
\left(\mathrm{m}^{3}\right)\end{array}$} \\
\cline { 4 - 5 } $\begin{array}{c}\text { Head } \\
(\mathrm{m})\end{array}$ & $\begin{array}{c}\text { Bank } \\
\text { height } \\
(\mathrm{m})\end{array}$ & $\begin{array}{c}\text { slope } \\
(\%)\end{array}$ & \begin{tabular}{c} 
Measured \\
\cline { 4 - 5 }
\end{tabular} & Simulated & $\begin{array}{c}\text { Percent } \\
\text { under/overestimated }\end{array}$ \\
\hline 0.3 & 0.4 & 0 & 0.00 & 0.05 & - \\
0.3 & 0.8 & 0 & 0.12 & 0.14 & 15.2 \\
0.6 & 0.8 & 0 & 0.17 & 0.17 & 4.3 \\
0.6 & 0.5 & 5 & 0.16 & 0.11 & -33.2 \\
0.6 & 0.5 & 10 & 0.17 & 0.17 & 1.1 \\
0.6 & 0.8 & 10 & 0.26 & 0.18 & -33.8 \\
\hline
\end{tabular}

$(100,95)$

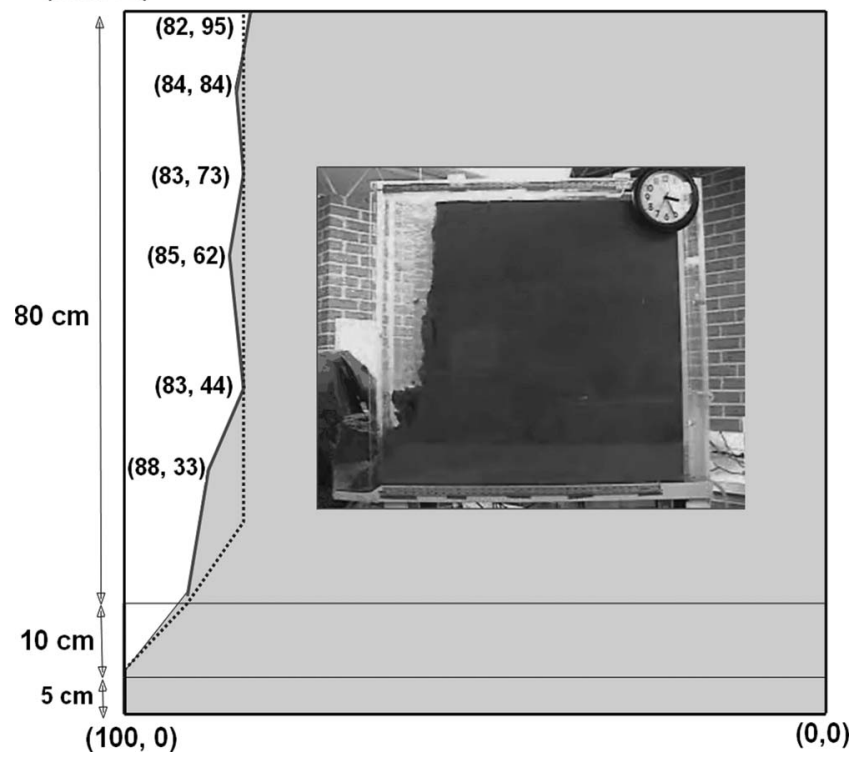

Fig. 9. Comparison of actual bank collapse (solid line) and SLOPE/W predicted critical slip surface (dotted line) generated for constant head, $H=0.3 \mathrm{~m}$, bank height, $\mathrm{BH}=0.8 \mathrm{~m}$, and slope, $S=0 \%$, lysimeter experiment. Observed bank collapse was $0.12 \mathrm{~m}^{3}$ while SLOPE/W predicted bank collapse was $0.14 \mathrm{~m}^{3}$. Note that inflow reservoir is on opposite side to that indicated in Figs. 2 and 5 .

The writers also acknowledge the technical assistance of Onur Akay, Research Engineer, Oklahoma State University, Stillwater, Okla. The writers also acknowledge Amanda Fox and three anonymous reviewers for reviewing an earlier version of this manuscript.

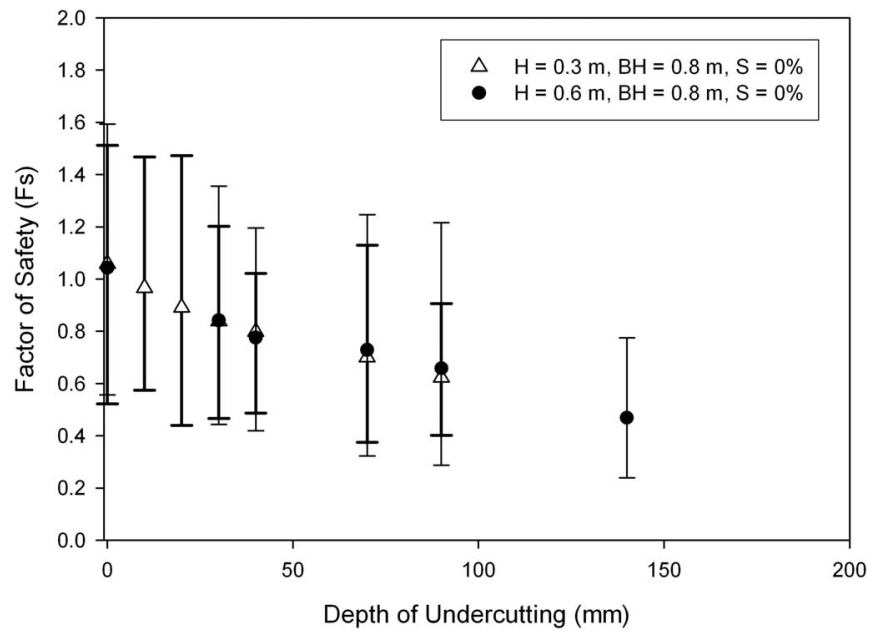

Fig. 10. Factor of safety $(F s)$ versus depth of undercutting for two experiments with same bank height $(\mathrm{BH}=0.8 \mathrm{~m})$ and slope $(S=0 \%)$ but different constant heads $(H=0.3$ and $0.6 \mathrm{~m})$. Error bars represent minimum and maximum $F s$ from 2,000 Monte Carlo simulations. 


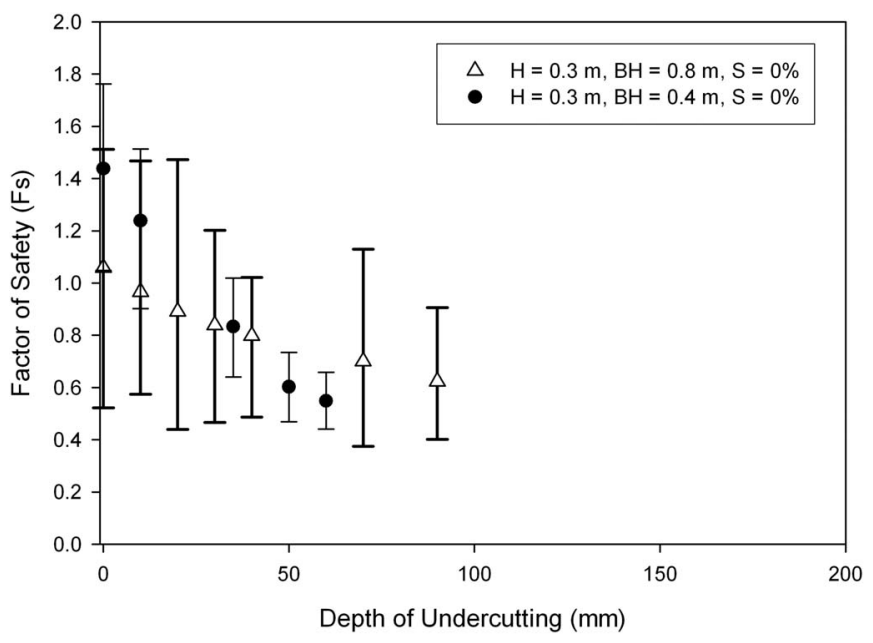

Fig. 11. Factor of safety $(F s)$ versus depth of undercutting for two experiments with same constant head $(H=0.3 \mathrm{~m})$ and slope $(S$ $=0 \%)$ but different bank heights $(\mathrm{BH}=0.4$ and $0.8 \mathrm{~m})$. Error bars represent minimum and maximum $F$ s from 2,000 Monte Carlo simulations.
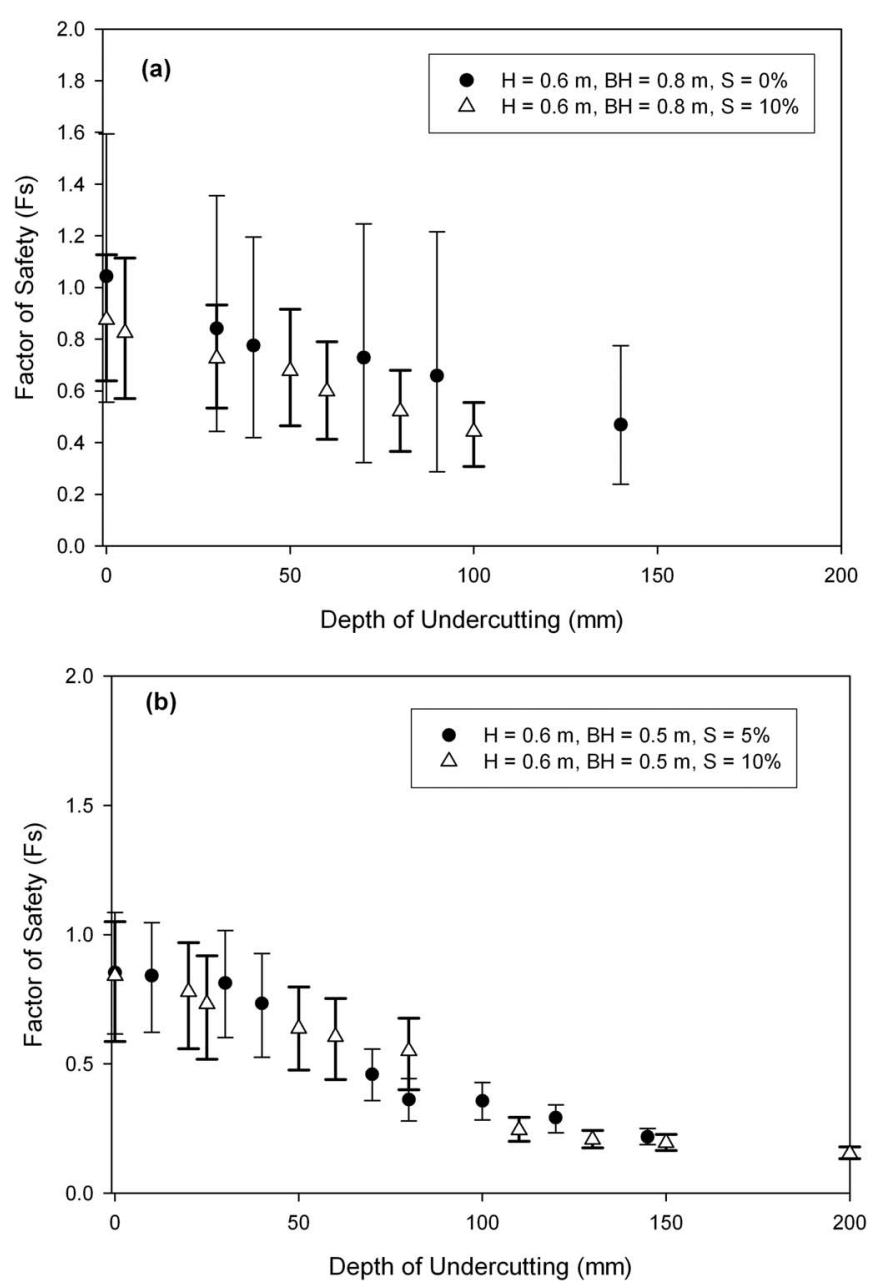

Fig. 12. Factor of safety $(F s)$ versus depth of undercutting for experiments with same constant head $(H=0.6 \mathrm{~m})$ and: (a) same bank height $(\mathrm{BH}=0.8 \mathrm{~m})$ but different slopes $(S=0$ and $10 \%)$; (b) same bank height $(\mathrm{BH}=0.5 \mathrm{~m})$ but different slopes $(S=5$ and $10 \%)$. Error bars represent minimum and maximum $F s$ from 2,000 Monte Carlo simulations.

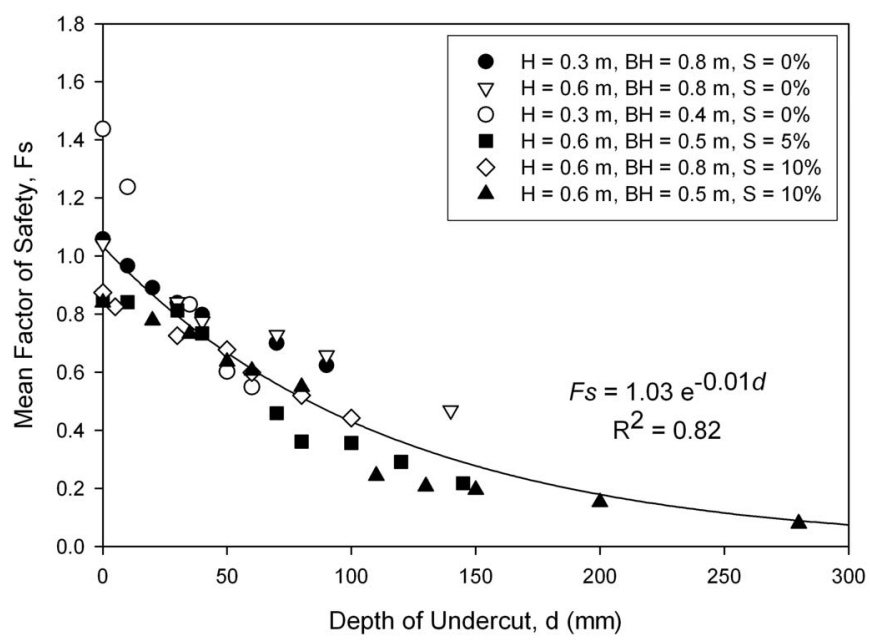

Fig. 13. Depth of undercutting, $d$, versus mean factor of safety, $F s$, of all six lysimeter experiments modeled with SLOPE/W

\section{References}

Abam, T. K. S. (1993). "Factors affecting distribution of instability of river banks in the Niger delta." Eng. Geol. (Amsterdam), 35, 123133.

Bryan, R. B., and Jones, J. A. A. (1997). "The significance of soil piping processes: inventory and prospect." Geomorphology, 20, 209-218.

Budhu, M., and Gobin, R. (1996). "Slope instability from groundwater seepage." J. Hydraul. Eng., 122, 415-417.

Burgi, P. H., and Karaki, S. (1971). "Seepage effect on channel bank stability." J. Irrig. and Drain. Div., 97, 59-72.

Caviness, K., Fox, G. A., and Deliman, P. N. (2006). "Modeling the Big Black River: Comparison of water quality models." J. Am. Water Resour. Assoc., 42(3), 617-627.

Crosta, G., and di Prisco, C. (1999). "On slope instability induced by seepage erosion." Can. Geotech. J., 36, 1056-1073.

Dapporto, S., Rinaldi, M., Casagli, N., and Vannoci, P. (2003). "Mechanisms of riverbank failure along the Arno River, Central Italy." Earth Surf. Processes Landforms, 28, 1303-1323.

Darby, S. E., Gessler, D., and Thorne, C. R. (2000). "Computer program for stability of steep cohesive riverbanks." Earth Surf. Processes Landforms, 25, 175-190.

Darby, S. E., and Thorne, C. R. (1996). "Numerical simulation of widening and bed deformation of straight sand-bed rivers. I: Model development." J. Hydraul. Eng., 122, 184-193.

Duncan, J. M., and Wright, S. G. (1980). "The accuracy of equilibrium methods of slope stability analysis." Eng. Geol. (Amsterdam), 16, $5-17$.

Edil, T. B., and Vallejo, L. E. (1980). "Mechanics of coastal landslides and the influence of slope parameters." Eng. Geol. (Amsterdam), 16, 83-96.

Evans, D. J., Gibson, C. E., and Rossell, R. S. (2006). "Sediment loads and sources in heavily modified Irish catchments: A move towards informed management strategies." Geomorphology, 79(1-2), 93-113.

Fox, G. A., Wilson, G. V., Periketi, R. K., and Cullum, R. F. (2006). "Sediment transport model for seepage erosion of streambank sediment." J. Hydrol. Eng., 11(6), 603-611.

Fox, G. A., Wilson, G. V., Simon, A., Langendoen, E., Akay, O., and Fuchs, J. W. (2007). "Measuring streambank erosion due to ground water seepage: Correlation to bank pore water pressure, precipitation, and stream stage." Earth Surf. Processes Landforms, 32(10), 1558-1573.

Hagerty, D. J. (1991). "Piping/sapping erosion. 1: Basic considerations." J. Hydraul. Eng., 117(8), 991-1008.

Hagerty, D. J., Spoor, M. F., and Ullrich, C. R. (1981). "Bank failure and erosion on the Ohio River." Eng. Geol. (Amsterdam), 17, 141-158. 
Hardy, R. J. (2006). "Fluvial geomorphology." Prog. Phys. Geogr., 30(4), 553-567.

Hooke, J. M. (1979). "An analysis of the processes of river bank erosion." J. Hydrol., 42, 39-62.

Huang, C., and Laflen, J. M. (1996). "Seepage and soil erosion for a clay loam soil." Soil Sci. Soc. Am. J., 60(2), 408-416.

Krahn, J. (2004a). Seepage modeling with SEEP/W: An engineering methodology, GEO-SLOPE International Ltd., Calgary, Alta., Canada.

Krahn, J. (2004b). Stability modeling with SLOPE/W: An engineering methodology, GEO-SLOPE/W International Ltd., Calgary, Alta., Canada.

Kusabe, O., Okumura, Y., and Nakase, A. (1987). "Centrifuge modeling of river bank failures." Proc., Int. Symp. on Flood Frequency and Risk Analysis, D. Reidel Publishing Company, Dordrecht, Holland, 399-408.

Lawler, D. (2005). "The importance of high-resolution monitoring in erosion and deposition dynamics studies: Examples from estuarine and fluvial systems." Geomorphology, 64, 1-23.

Lourenco, S. D. N., Sassa, K., and Fukuoka, H. (2006). "Failure process and hydrologic response of a two layer physical model: Implications for rainfall-induced landslides." Geomorphology, 73, 115-130.

Morgenstern, N. R., and Price, V. E. (1965). "The analysis of the stability of general slip surfaces." Geotechnique, 15, 79-93.

Owoputi, L. O., and Stolte, W. J. (2001). "The role of seepage in erodibility." Hydrolog. Process., 15(1), 13-22.
Periketi, R. (2005). "Analysis of seepage erosion with lysimeter experiments and numerical modeling." MS thesis, Univ. of Mississippi, University, Miss.

Rinaldi, M., and Casagli, N. (1999). "Stability of streambanks formed in partially saturated soils and effects of negative pore water pressures: The Siene River (Italy)." Geomorphology, 26, 253-277.

Rockwell, D. L. (2002). "The influence of groundwater on surface flow erosion processes." Earth Surf. Processes Landforms, 27(5), $495-514$.

Simon, A., Curini, A., Darby, S. E., and Langendoen, E. J. (1999). "Streambank mechanics and the role of bank and near-bank processes in incised channels." Incised river channels, S. E. Darby and A. Simon, eds., Wiley, Chichester, U.K., 193-217.

Simon, A., and Darby, S. E. (1997). "Disturbance, channel evolution and erosion rates: Hotophia Creek, Mississippi." Proc., Conf. on Management of Landscapes Disturbed by Channel Incision, S. S. Y. Wang, E. J. Langendoen, and F. D. Shields, eds., Univ. of Mississippi, Oxford, Miss., 476-481.

van Genuchten, M. T. (1980). "A closed-form equation for predicting the hydraulic conductivity of unsaturated soils." Soil Sci. Soc. Am. J., 44(5), 892-898.

Wilson, G. V., Periketi, R. K., Fox, G. A., Dabney, S. M., Shields, F. D., and Cullum, R. F. (2007). "Seepage erosion properties contributing to streambank failure." Earth Surf. Processes Landforms, 32(3), $447-459$. 